\title{
doispontos:
}

\section{Nebulosa de Imunidades? Sobre estado de direito e democracia no pensamento jurídico brasileiro}

\author{
Immunities Nebula? On the rule of law and democracy in Brazilian legal thinking
}

\author{
Andrei Koerner \\ andreiko@uol.com.br \\ Professor associado do Depto. de Ciência Política do IFCH/Unicamp \\ Valeriano Costa \\ Professor do Depto de Ciência Política do IFCH/Unicamp \\ Diretor do CESOP \\ vmfc@unicamp.br
}

\begin{abstract}
Resumo: $O$ artigo propõe uma análise multidisciplinar sobre o pensamento jurídico, tendo como objetivo a reflexão crítica sobre os saberes e práticas jurídicos na sociedade brasileira. $\mathrm{O}$ artigo elabora inicialmente uma análise crítico-conceitual de trabalhos de Guillermo O’Donnell sobre estado de direito e democracia na América Latina. Em seguida, adota a noção de agregados jurídicos para apresentar distintas dimensões de pesquisas sócio-jurídicas sobre o direito. Enfim, usa a metáfora da nebulosa de imunidades para a proposta de discernir os atributos positivos do estado de direito no pensamento jurídico brasileiro e suas consequências para a democracia.

Palavras-chave: Democracia, estado de direito, análise política do pensamento jurídico, história constitucional, política brasileira, Judiciário e política
\end{abstract}

\begin{abstract}
The article proposes a multidisciplinary analysis of legal thinking, aiming at a critical reflection on legal knowledge and practices in the Brazilian society. The article initially goes over a critical-conceptual analysis of Guillermo O'Donnell's work on the rule of law and democracy in Latin America. Then, it adopts the notion of juridical assemblages to present different dimensions of the socio-legal researches on law. Finally, it uses the metaphor of the "immunities nebula" for the proposal of discerning the positive attributes of the rule of law in the Brazilian legal thinking and its consequences for democracy.

Key-words: Democracy, rule of law, political analysis of legal thinking, constitutional history, Brazilian politics, Judicial politics
\end{abstract}




\section{Introdução}

O termo provocativo do título é uma metáfora que questiona as relações entre estado de direito e democracia no Brasil para se propor uma análise multidisciplinar sobre o pensamento jurídico, tendo em vista a reflexão crítica sobre os saberes e práticas jurídicos nas condições sociais e políticas da formação histórica da sociedade brasileira.

Tomamos como dados os resultados de pesquisas históricas e sócio-jurídicas sobre as especificidades das instituições e práticas judiciais, assim como a crítica a abordagens correntes sobre o tema. Essas abordagens assumem, por um lado, a inviabilidade ou a irrelevância do estado de direito entre nós, em virtude de determinantes estruturais, o modo de relações entre as classes sociais e padrões culturais das elites dirigentes ou, por outro lado, a suposição de autonomia e separação das esferas jurídica e política, em relação a outras condições sociais, assumidas por análises correntes em ciência política, que discutem temas como a judicialização da política e o ativismo judicial. Essas análises presumem a distribuição de papéis entre legisladores, governantes e juízes na democracia representativa, enquanto aqui se exploram as consequências das análises de $\mathrm{O}^{\prime}$ Donnell sobre a impertinência deste conceito.

Trata-se, neste artigo, de apresentar uma discussão mais geral e exploratória sobre um aspecto muito importante da nossa experiência nos últimos anos, que tem antecedentes de longa duração e se recompõe conforme as viradas conjunturais, tal como nos embates atuais da crise no Brasil. Esse aspecto é o da multiplicidade de facetas que assume o discurso do estado de direito promovido pelos juristas, e que se traduz em incerteza para os sujeitos e numa situação mais geral de baixa efetividade e falta de objetividade dos direitos na ordenação das relações sociais.

Poder-se-ia chamar a multiplicidade de metamorfoses ou transformações, mas é algo mais frequente e incerto, como se fosse uma composição constante de cores e tonalidades, de sentidos e polaridades que estão presentes em nossas interações sociais, práticas governamentais, formatos institucionais. Poder-se-ia relembrar máximas como "aos amigos, tudo e aos inimigos, a lei", ditados populares como o de que não é possível esperar o que sai da caneta de um juiz, o jeitinho, a malandragem. Sabe-se que há explicações históricas e sociológicas, e de senso comum, tais como as relações de compadrio, o favor, o patrimonialismo, a dualidade estrutural entre igualdade das relações de mercado e a desigualdade das relações interpessoais etc.

Existiria a possibilidade de optar entre explicações polares: por um lado, a análise estrutural que coloca os termos como expressões da formação social capitalista periférica e, por outro, o patrimonialismo que marca as orientações da ação dos dirigentes que confundem o público com seus interesses privados. A ambiguidade e incerteza sobre o sentido objetivo da lei poderiam ser interpretadas como efeito de uma marca estrutural ou de um padrão cultural na sociedade brasileira. Mas com esse tipo de explicação não se abre a "caixa-preta" do jurídico e assim as práticas judiciais e conceitos jurídicos não se tornam objetos de análise a serem pesquisados e refletidos, pois eles são tomados como dados, como efeito de superfície ou artifício retórico daquilo que acontece "sob o verniz das idéias".

O esvaziamento do jurídico como objeto de análise e reflexão não é mais um problema, pois nos últimos quarenta anos muita pesquisa foi feita sobre o tema, no Brasil e noutros países, a partir de várias perspectivas teóricas e campos disciplinares. Mas há o risco de, no interior desse campo de pesquisas, manter-se uma polarização entre os que sustentam empiricamente a relação causal direta entre a incerteza constante na aplicação das normas jurídicas e as características estruturais ou culturais do país e, por outro lado, os que partem da premissa da autonomia do jurídico ou do político ou aqueles que buscam na efetividade pontual do estado de direito em conjunturas políticas, sociais ou culturais evidências que confirmariam alguma tendência à afirmação e ampliação daquela autonomia. No entanto, a oposição 
acabaria por bloquear o que nos parece ser o objetivo central de pesquisas sobre o tema: o de tomar como objeto de análise a própria incerteza do estado de direito, as suas bases, configurações, pontos de tensão e momentos de descontinuidade. Em outros termos, afirmamos que as violações do estado de direito não significam sua impossibilidade, inviabilidade ou inefetividade global, nem procuramos nos eventos em que ele se realiza os sinais de um processo gradual de sua realização. Trata-se olhar para a combinação entre a vigência do estado de direito e suas violações como partes de um conjunto que se sustenta, que se compõe numa combinação de agregados mais do que num sistema, e no qual as regras jurídicas se mantêm em sua particularidade e eficácia pontual, mas sem generalização nem objetividade.

Essa configuração não pode ser vista fora de sua conformação espaço-temporal, isto é, como relações constituídas historicamente (HALL, 2015). Desse modo, nossa análise do estado de direito não se resume a evidenciar a sua negação resultante de violações recorrentes (o "não estado de direito"). Insistimos aqui na relevância de identificar e analisar configurações positivas, com determinados atributos que se combinam de maneira variável em modelos e normas historicamente determinados em casos concretos, assim como situações de violações, de desvio estratégico, de indiferença ou de afrontamento direto àqueles modelos e normas.

Em nossa visão, um programa de trabalho pode ser construído em torno da pesquisa daquilo que denominamos "nebulosa de imunidades", caracterizando-a em suas "formas jurídicas", suas relações com determinadas estruturas e processos sociais (e políticos), suas transformações etc. Neste artigo nos limitamos a apresentar alguns pontos dessa proposta, que tem como o pensamento jurídico sobre o estado de direito, suas relações com o conjunto de agregados jurídicos e suas formas sociais. Partimos da análise crítica do tema do "não-estado de direito na América Latina” proposto por Guillermo O 'Donnell. Os seus trabalhos são relevantes por discutirem as teorias empíricas da democracia em ciência política, com preocupação normativa e comparativa. Na sua crítica àquelas teorias, o autor evidencia as relações internas entre democracia e estado de direito, chamando a atenção para as características e trajetórias das democracias latino-americanas. Porém, ele não elabora os problemas teóricos e de pesquisa empírica sobre o estado de direito que suas análises implicam ${ }^{1}$.

A segunda seção propõe a noção de agregados jurídicos em substituição às de Estado enquanto legalidade ou de sistema legal adotadas pelo autor. A noção designa o conjunto heterogêneo de instituições, doutrinas e práticas que compreendem o termo "direito" em sentido sócio-jurídico. Apresentam-se ilustrações para mostrar a variedade de aspectos do agregado e possíveis dimensões para a pesquisa e análise.

A terceira seção discute as noções de estado de direito e (não) estado de direito do ponto de vista das relações entre o ideal, os agregados jurídicos e sociedade, assim como as implicações do pensamento e os saberes jurídicos para o estado de direito e a democracia. Propõe-se o termo "nebulosa de imunidades" para designar aquelas situações de falta de nitidez, de ambiguidades e incertezas naquelas relações e se discutem possíveis desdobramentos analíticos a partir dele.

\section{1 - Democracia e (não) estado de direito na América Latina na obra de O'Donnell}

O trabalho de Guillermo O'Donnell é importante no pensamento latino-americano por tratar as relações entre democracia, Estado e cidadania em discussão crítica com os modelos de análise empíricos da democracia adotados pela política comparada internacional, impulsionada e dirigida pelos norte-

\footnotetext{
${ }^{1}$ Depois da análise crítica do autor, nosso escopo limita-se ao pensamento e práticas jurídicas no Brasil, dado que nossa formação e objetivos intelectuais não são no campo da política comparada nem no da teoria política.
} 
americanos no pós-Segunda Guerra ${ }^{2}$. Em suas análises sobre as especificidades da democracia latinoamericana, $\mathrm{O}^{\prime}$ Donnell não só incorpora referências históricas, sociológicas e culturais, mas também faz a crítica à ciência política a partir da teoria política normativa, e se vale da teoria do direito para elaborar as relações entre Estado, democracia e estado de direito.

Nos anos setenta, ele trabalhou as relações entre Estado, modernização e capitalismo na América Latina, com o objetivo de apontar o particularismo dos pressupostos universalistas das teorias da modernização, ao mesmo tempo em que mantinha distância com relação às teorias da dependência (O 'DONNELL, 1972 e 1979). Em meados dos anos oitenta, publicou uma importante pesquisa comparada sobre as transições à democracia na América Latina e Sul da Europa na qual a análise colocava-se no nível do regime político e tinha como foco as interações estratégicas entre atores políticos (O'DONNELL, SCHMITTER e WHITEHEAD, 1988). A partir do início dos anos noventa, ele se distancia do tema da consolidação da democracia, sobre o qual os analistas discutiam etapas de transição e critérios de estabilidade das novas democracias (O'DONNELL, 1996a). Para ele, o que estava em jogo nas novas democracias era uma outra institucionalização, um processo histórico com dinâmica e características próprias. Por isso, estas não poderiam ser compreendidas exclusivamente com base na comparação com as democracias consolidadas. Não se devia pensar em democracias como modelos formais estáticos ou institucionalizados. Na sua concepção, os regimes políticos seriam estruturados em torno de regras jurídicas de acesso e exercício do poder, e redes (sociais, políticas e administrativas) de controle (accountabillity) horizontais e verticais (O'DONNELL, 1998). Os regimes democráticos se configurariam como processos dinâmicos de democratização $-e$ (des)democratização, que se conformariam, estabilizariam e recomporiam continuamente.

Assim, ele questionou o cerne das teorias mainstream da democracia em ciência política e abriu espaço para propor uma outra abordagem. Ele passou a explorar as relações entre regime político e suas condições políticas (Estado) e o reconhecimento da capacidade de agência, dentro de um conjunto maior de fatores econômicos, sociais e culturais historicamente constituídos (estrutura de classe, tradições).

Entre meados dos anos noventa até o seu falecimento em 2011 ele publicou uma série de artigos cujos temas serão condensados no seu livro Democracia, Agência, Estado (O'DONNELL, 2010 e 2011). Os temas são, principalmente a crítica conceitual interna às teorias procedimentalistas ou minimalistas da democracia e a análise e reflexão sobre a trajetória histórica da América Latina e dos regimes democráticos que aqui se institucionalizaram. Ao mesmo tempo, fez elaborações teóricas e normativas sobre democracia, direitos humanos e desenvolvimento, sintetizadas no tema da qualidade da democracia. Elaborou teoricamente as relações internas democracia, direitos humanos, paz e desenvolvimento, tal como reconhecido pela Declaração da Conferência de Viena em 1993. No início dos anos 2000, ele formulou o quadro analítico para o projeto do Programa das Nações Unidas para o Desenvolvimento (PNUD) cujo objetivo era criar indicadores para avaliar a situação da democracia em cada país da região. Esse trabalho, que mais tarde será incluído na coletânea The Quality of Democracy (O'DONNELL, 2004), complementou a sua proposta de análise empiricamente informada das dinâmicas e obstáculos da democracia na América Latina ${ }^{3}$.

\section{Da crítica às teorias minimalistas à teoria ampliada da democracia}

Em sua crítica conceitual às teorias minimalistas de democracia, $\mathrm{O}^{\prime}$ Donnell estava interessado em elaborar um conceito empírico-analítico de democracia capaz de abarcar as especificidades das democracias não-ocidentais, irredutíveis às trajetórias históricas das democracias mais antigas e institucionalizadas

${ }^{2}$ Sobre a trajetória de O’Donnell, ver Brinks et al, 2014.

${ }^{3}$ Sobre as relações entre as dimensões normativa e empírica do seu trabalho, ver Whitehead (2014). 
do "quadrante Noroeste" (a Europa ocidental e a América do Norte) (O'DONNELL, 1999). Na sua abordagem, um conceito ampliado de democracia teria que compreender as condições sociais mais amplas e levar em conta os efeitos de processos de longa duração constitutivos das diferentes dinâmicas democráticas. Com isso, ele não só rompia a unidade teórica da definição mínima da democracia, mas também propunha a reconstrução do conceito de democracia, relacionando-o com a agência e o Estado, o que ele fez em seus últimos trabalhos (CULLEL, 2014).

Em nome da economia conceitual, as teorias minimalistas estabelecem condições restritivas da democracia cujo foco é a seleção dos dirigentes em eleições competitivas, livres, com eleitorado amplo e a alternância no poder entre grupos políticos institucionalizados. O'Donnell (2011 e 1999) mostra as premissas implícitas daquelas teorias, que compreendem três pontos: o da democracia como regime juridicamente institucionalizado, o seu micro-fundamento na capacidade de agência e as suas macro-condições na relação com o Estado. Ele aceita os critérios das definições minimalistas, mas completa que as eleições devem ser decisivas e institucionalizadas, o que significa, em resumo, que os resultados serão aceitos e os vencedores governarão, e que novas eleições acontecerão segundo o calendário previsto por um futuro indeterminado. A democracia é, portanto, um regime político (a definição está em O'DONNELL, 2011, p. 30), com regras do jogo estáveis e com vigência indeterminada, às quais todos adaptam suas expectativas e estratégias. Para serem competitivas, as eleições pressupõem um conjunto de liberdades cívicas e de direitos políticos de cidadania dos eleitores, cujas raízes estão nos direitos civis socialmente institucionalizados.

Nas concepções minimalistas de democracia, a unidade de análise é aquele que vota, o eleitor, o que supõe que ele seja titular de um complexo de direitos enquanto cidadão político e de outros (direitos civis, cívicos) que são implícitos nesse estatuto, mas que lhe são necessários enquanto membro da comunidade política nacional, cujo reconhecimento e efetividade são dados. Esse complexo de direitos significa o reconhecimento da capacidade de agência de caráter universalista e igualitário dos direitos de cidadania e este é o ponto fundamental de sua teoria. O seu argumento básico é que "a democracia... pressupõe a concepção do ser humano como um agente que adquiriu... o título de ser reconhecido e legalmente amparado como um portador de direitos à cidadania..." em sentido amplo. O ser humano como agente titular de direitos é o micro fundamento que enraíza os aspectos empíricos e normativos da democracia (O'DONNELL, 2011: 7; WHITEHEAD, 2014). O agente é "alguém dotado de razão prática e discernimento moral, que usa sua capacidade intelectual e motivação para tomar decisões que, em princípio são razoáveis em função de sua situação e objetivos", sobre os quais é, em princípio, o melhor juiz (id., p. 43). A condição de cidadão titular de direitos significa o reconhecimento da capacidade de agência de todos os indivíduos, independentemente de condições sociais, com algumas exceções legais, de tomarem decisões razoáveis e que podem ter consequências importantes (id., p. 35). Do ponto de vista político, a democracia é uma "aposta institucionalizada" cuja implicação é que cada um deve aceitar que qualquer outro participe como eleitor ou candidato e que, sendo eleito, governe durante o período do seu mandato (id., p. 36).

O regime democrático é parte constitutiva de um processo de formação estatal ao qual está historicamente subsumido (MANN, 1992). O 'Donnell define o Estado como uma associação de caráter atributivo (nãovoluntária) de base territorial, com instituições que organizam as relações sociais, detém o monopólio da autorização legítima do uso da coerção física e normalmente tem a supremacia no controle dos meios de coerção (O'DONNELL, 2011, p. 66). Ele distingue quatro dimensões para a análise do Estado: a organizacional, do conjunto de burocracias, que dizem respeito à eficácia do Estado no território; a do sistema legal, que se refere à efetividade das suas normas para ordenar as relações sociais; a da identidade coletiva, um "nós" que prevalece sobre as várias parcialidades e confere credibilidade ao Estado; enfim, a territorial, de regulação das relações internas/externas, e que se refere à filtragem do Estado (id., pp. 68-9). 


\section{As democracias da América Latina}

O contraste entre as democracias na América Latina e as democracias mais antigas "do Noroeste", é central em várias de suas publicações nos anos noventa (O'DONNELL, 1991, 1994, 1996a e 1998). As diferenças compreendem aspectos políticos, sociais e culturais e aparecem nos três níveis do regime, do Estado e da cidadania. A democracia latino-americana elege seus dirigentes por delegação, um modo distinto da democracia representativa, o Estado realiza-se de forma heterogênea e pouco confiável, configurando-se situações de estatalidade incompleta ou limitada. Por isso, a efetividade dos direitos é precária para grandes parcelas da população e vastas regiões do território, o que o leva a qualificar a cidadania como de baixa intensidade.

Um conceito central na análise de O 'Donnell é o de "democracia delegativa”, construído analiticamente em contraposição ao de "democracia representativa” (O'DONNELL, 1991, 1994, 1998). A democracia representativa seria caracterizada como um regime que combina as três tradições do pensamento político ocidental: a base na eleição popular (democracia), a proteção dos direitos (liberalismo) e a virtude do exercício do governo para o bem público (republicanismo). Entretanto, essas tradições estão institucionalizadas não apenas em regras, organizações e procedimentos jurídicos, mas também em um ethos democrático, que orienta a ação e as expectativas de dirigentes e cidadãos. Um elemento central na sua abordagem sobre a democracia representativa éo de controles públicos (accountability) (O'DONNELL, 1998). As democracias representativas distinguem-se especificamente das democracias delegativas por uma rede institucionalizada de procedimentos e organizações de controle, horizontais e verticais. Esta rede écrucial para assegurar que a atuação dos governantes e dos cidadãos se oriente segundo as regras e princípios configurados pelas três tradições referidas acima. Os controles horizontais são instituições dentro do Estado que compreendem a separação dos poderes, mas também um amplo conjunto de organizações especializadas no controle da atividade governamental, tais como as agências independentes ou os Tribunais de Contas e o Ministério Público. Os controles verticais são de dois tipos, por um lado, as eleições livres periódicas com amplas possibilidades de participação e de contestação, cuja ocorrência é necessária para se classificar um regime como democrático. E, por outro lado, os controles sociais, tais como movimentos sociais, sindicatos, imprensa livre, que apresentam demandas, realizam pressões sobre o governo e resistem a eventuais tentativas de os governantes se excederem no exercício do poder. Haveria, então, a tendência ao predomínio de um ethos universalista de respeito às regras e de separação entre os interesses público e privado.

A democracia por delegação ${ }^{4}$ na América Latina e em outras regiões do mundo se organiza a partir de noções políticas distintas, pois nelas as tradições liberal e republicanas são menos fortes e a democrática também está menos presente (O'DONNELL, 1996a e 1998). Em meados dos anos noventa O'Donnell argumentou que, embora houvesse na América Latina alguns regimes políticos classificados como "democracias estáveis" (na Colômbia e na Venezuela), estes apresentavam diferenças significativas em relação às suas congêneres do "Noroeste". Naqueles, as eleições, mesmo relativamente competitivas e periódicas, configuravam na prática, formas de delegação do exercício do poder ao dirigente que se considerava autorizado a governar como lhe aprouvesse, como exercício da sua vontade, face à qual as normas legais e os controles seriam obstáculos. Isso porque essas democracias por delegação teriam organizações de accountability horizontais inócuas e redes de accountability sociais verticais frágeis. Elas seriam fragilizadas também pelo ethos e orientações de ação particularistas e privatistas, que favoreceriam práticas patrimonialistas no Estado, de cooptação e clientelismo sobre setores significativos do eleitorado. Por fim, seriam também limitadas pela baixa capacidade de organização da população, resultantes da pobreza, dos baixos níveis educacionais, assim como concepções tradicionais sobre as relações de mando e obediência.

\footnotetext{
${ }^{4}$ Adotamos esse termo para diferenciar do tipo "democracia delegativa" explicado a seguir.
} 
O'Donnell formula o tipo empírico democracia delegativa para caracterizar uma situação extrema e instável desses regimes. Em crises econômicas ou políticas graves surgem dirigentes políticos com ares salvacionistas (tais como Menem, Collor e Fujimori, e se pode incluir Bolsonaro, sem dúvida) que procuram governar por decretos, com base em movimentos (e não partidos), que falam diretamente para a massa da população reivindicando uma delegação de poder ilimitado, e por isso veem como obstáculos as instituições de divisão dos poderes e os procedimentos de controle entre eles (O'DONNELL, 1991; 1994; O’DONNELL, IAZZETTA e QUIROGA, 2011).

Como regimes emergentes de processos de formação estatal, as democracias representativas (mas, também as delegativas) estão condicionadas pelas capacidades historicamente construídas de territorialidade e centralização dos seus respectivos Estados (MANN, 1992). Isto é, supõe-se que os regimes efetivamente democráticos sejam capazes de ordenar as relações sociais e controlar as situações de conflito que emerjam no seu território.

A análise histórico-comparada de $\mathrm{O}$ 'Donnell mostrou diferenças significativas entre as democracias do "Noroeste" e as democracias latino-americanas. Nas primeiras houve um processo histórico de longa duração que resultou numa grande concentração dos meios de coerção física (exércitos profissionais), na criação de meios de administração (burocracias profissionais), na expropriação pelo rei dos meios de legalidade e de jurisdição, promovendo a centralização do direito (poder judiciário independente), na criação de fortes identidades nacionais e no controle territorial centralizado pelo Estado nacional. Apesar de suas diferentes trajetórias, elas teriam um grau alto de completude ou realização dos processos de construção estatal e de identidade nacional. $O$ resultado é que o Estado moderno e o regime democrático são historicamente (quase) concomitantes, a sua convergência unificou Estados e governos com as suas populações, e a nação forneceu a base cultural da cidadania política e do Estado. Nesses casos, o Estado tornou-se promotor e garantidor da cidadania, lugar de reconhecimento de direitos pela ordenação jurídica estatal e de sua implantação dos direitos por meio de burocracias (O'DONNELL, 2011, p. 80-90; 103-4; 112) .

Na América Latina, comparativamente, os Estados têm um desempenho medíocre, embora desigual, nestas quatro dimensões. Em primeiro lugar, as suas burocracias parecem incapazes de controlar (e mesmo ocupar) todo o território nacional e quando o fazem mostram-se pouco efetivas. O sistema legal é aplicado de forma desigual e socialmente enviesada. Por isso a percepção dos cidadãos (especialmente os pobres) quanto à capacidade dos Estados e governos para realizarem alguma noção de bem comum é também muito negativa. Enfim, seu desempenho não é melhor quando observamos a sua capacidade de gestão das fronteiras, assim como a inserção na economia. Estes países apresentam histórias desarticuladas no processo de formação estatal, sociedades estruturalmente heterogêneas, espaço social polarizado e fragilidade na formação (recrutamento) de sua burocracia e imposição de uma legalidade considerada legítima. Por tudo isso, afirma $\mathrm{O}^{\prime}$ Donnell, a democracia nestes países não é capaz de produzir efeitos igualitários e niveladores, ficando à deriva entre uma sociedade fragmentada e um Estado ineficiente (id., p. 174-7; 185).

Sobre as diferenças na capacidade de agência, o autor as coloca como diferenças no grau de efetividade dos direitos de cidadania e nas condições sociais de vida. O eleitor exerce seu direito como cidadão político que, por sua vez, supõe o cidadão tout court, o membro da comunidade nacional com um complexo de direitos e obrigações reconhecidos e institucionalizados. Mas para exercer esses direitos, são necessárias condições de estatalidade, ou seja, que as relações sociais no território sejam reguladas pelas organizações

\footnotetext{
${ }^{5}$ Uma visão alternativa deste processo pode encontrada em Charles Tilly (1996). Para ele, o processo de formação dos estados europeus implicou na complexa (e variável) articulação entre Coerção (estatal) e Capital (mercado) resultando na transformação das formas de dominação do que ele denominou de "governo indireto" (estado tradicional) para "governo direto" (estado moderno. Nesta abordagem, tal como em O 'Donnell, a cidadania e a democracia são processos emergentes e não autônomos (TILLY, 2013).
} 
estatais e que o sistema legal ordene as orientações de ação e interações sociais. Além disso, os cidadãos devem ter condições adequadas de vida, educação e capacidade de agência propiciados pela efetividade dos direitos civis, sociais e culturais.

Ele faz um excurso histórico de longa duração para mostrar como, desde o início da modernidade, houve no "Noroeste" a expansão gradual dos direitos até a institucionalização da democracia constitucional da atualidade ((id., cap. 2). Nas demais regiões ocorreu a ampliação "abrupta" do direito ao sufrágio, resultando em instabilidades políticas, regressões autoritárias e precariedade dos direitos. Mas em todas as democracias do mundo houve exclusões, limitações e discriminações, num processo histórico de lutas pelo reconhecimento de direitos (id., p. 62).

Na América Latina, a situação é paradoxal, em comparação com a trajetória clássica de reconhecimento dos direitos (ver MARSHALL, 1950), onde o reconhecimento formal de direitos é relativamente amplo, mas com precária efetividade. Configura-se aqui uma cidadania de baixa intensidade em que os indivíduos são legal e materialmente excluídos do acesso a direitos. A lei estatal, então, é substituída por regras locais e tradicionais, impostas por grupos que, na periferia, se apropriam de espaços que deveriam ser controlados pelo Estado (TOKMAN e O'DONNELL, 1998; O'DONNELL, 1996b). Há vários gaps de legalidade, numa outra ordem diferente da legal, em que dominantes locais e intermediários selecionam e determinam as condutas válidas. As normas legais homogêneas não produzem os mesmos efeitos para pessoas situadas em contextos diferentes, criando problemas que afetam a atuação do próprio regime democrático (O’DONNELL, 2011, p. 146-8). Na América Latina, a extensão dos direitos civis era incompleta quando ocorreu a democratização ou a ampliação dos direitos políticos. Tem-se leis discriminatórias e não equitativas, cuja aplicação é arbitrária e não têm efetividade universal. As isenções e privilégios para os poderosos combinam-se com o rigor aplicado contra os pobres. As relações da burocracia com os cidadãos ordinários são assimétricas, com tratamento não respeitoso da dignidade humana, e o acesso ao judiciário e ao processo justo é limitado e caro. Em outras situações, tem-se a ilegalidade pura e simples, dado que o Estado não é capaz de ocupar o território, ou, embora esteja formalmente presente, a burocracia não é capaz de regular as relações sociais e assim a legalidade não se torna referência para o governo das condutas nas interações. Em outras situações, as leis são aplicadas, se o forem, de forma intermitente e diferencial em lugares amplos do território estatal. A lei estatal é confrontada por "regras informais" impostas por grupos de poder privados que dominam regiões inteiras, tanto em áreas rurais isoladas como periferias das grandes conturbações. O que há, portanto, é uma constante negociação entre a legalidade formal e normas informais. Além disso, os "sistemas de regras informais" são pontuados por intervenções arbitrárias do sistema formal, que sustentam um mundo de extrema violência. Em muitos casos, mesmo os sistemas subnacionais formais (governos estaduais, provinciais, departamentais e municipais) convivem com "sistemas de regras informais" que coexistem, por sua vez, com sistemas nacionais poliárquicos (O’DONNELL, 1999: 311-4; 1996b) ${ }^{6}$.

Assim, estatalidade incompleta, inefetividade do sistema legal e cidadania de baixa intensidade sintetizam a situação de (não) estado de direito que é complementar ao regime de democracia por delegação. $O$ termo estado de direito perpassa o Estado, o regime e a capacidade de agência, uma vez que ele releva das formas de accountability (regime), de regulação burocrática e ordenação das relações sociais (Estado) e da cidadania (agência).

\section{O Estado de direito}

\footnotetext{
${ }^{6}$ Outros autores são mais otimistas. Edward Gibson (2013) defende que a democratização dos governos nacionais na América Latina é apenas um primeiro passo na difusão da democracia por todo o território nacional. Baseado em estudos de casos no México e na Argentina conclui que subsistem "enclaves" subnacionais autoritários que frequentemente negam o acesso a direitos civis e políticos aos cidadãos locais.
} 
O'Donnell define estado de direito (rule of law)7, como um ideal político ou horizonte normativo destacando-se em primeiro plano as dimensões sistemáticas e formais do conceito. Assim, depois de apontar para a diversidade de definições e experiências históricas a que se referem o termo "estado de direito" nas diversas línguas, ele assume que a ideia básica é o do governo das leis e não o dos homens. O cerne comum a todos os sistemas legais poderia ser resumido a um conjunto de normas hierárquicas, que tenderiam (e visariam) à completude; que as relações entre essas normas seriam definidas por regras formais, que os governantes (rulers) deveriam ser submetidos às leis como todos os outros, e que todos deveriam ser submetidos às regras em todas as situações, sem exceção, ou seja, que ninguém poderia ser legibus solutus (O’DONNELL, 2011, p. 116-7).

O autor salienta que, na tradição do common law, as definições do rule of law centram-se nas cortes, enquanto em outras línguas o termo estado de direito abrange todas as instituições estatais e, tendencialmente, todas as relações sociais. Enquanto um ideal, o estado de direito tem implicações institucionais e sociais bastante efetivas, mas, por definição, ele é sempre incompleto e se realiza em maior ou menor grau. O grau de sua realização é relativo ao alcance da democracia no Estado e na sociedade, e daí que, quanto maior for a abrangência e a efetividade do estado de direito, mais forte será o Estado e o regime democrático que ele contém (id., pp. 120 e 136).

Ele destaca que o atributo crucial do estado de direito para o sistema legal é que ele "fecha" todos sob a lei, não há ninguém fora das suas regras nem pode ignorá-las. Ele é ficção útil, pois nem os governantes nem outros cidadãos podem dispor das regras e estas se compõem em sistema, um conjunto articulado, hierarquizado e consistente de regras dotado de unidade formal. A ficção tem várias consequências: governantes e funcionários estatais têm direitos próprios, diferentes dos cidadãos (o uso da coerção), mas o seu uso é estritamente regulado; a diferença entre público e privado torna-se estrita e controlada; o sistema legal não só protege direitos individuais, mas também capacita os cidadãos para o exercício de direitos coletivos. O sistema legal sustenta e sanciona meios pacíficos de tomada de decisão coletiva que viabilizam a agência autônoma dos cidadãos. Daí que são necessários procedimentos equitativos, disponíveis a todos e institucionalizados legalmente. Outra consequência seria que os cidadãos têm expectativas em relação ao desempenho de governantes e funcionários para o bem comum e têm instrumentos para controla-los. Uma tensão seria posta pelo próprio direito cujas regras indeterminadas e procedimentos dialéticos ou argumentativos, colocaria em contrariedade a expectativa de estabilidade das regras e a participação dos cidadãos para a mudança das leis, ou para alterar os sentidos dominantes a ela atribuídos (id., p. 127-8).

O'Donnell esclarece que sua exposição sobre o estado de direito não é no campo da teoria do direito mas releva os aspectos relevantes da legalidade estatal na democracia (id., p. 115, n. 1; CULLEL, 2014, p. 311). Ele discute também as relações entre estado de direito e cidadania, com destaque para a ambivalência da legalidade estatal igualitária e o papel do Estado como organizador da desigualdade, dadas pela exploração capitalista, discriminações e relações sociais de poder. Ele apresenta a relação entre Estado como burocracia e a legalidade, dada a relevância de controles legais sobre as relações internas às organizações burocráticas.

Ao longo de todo o capítulo sobre o Estado como legalidade, ele faz ressalvas e observações sobre a não realização do estado de direito e as suas implicações para a prática do direito, mas não desenvolve o ponto. A questão é desenvolvida em apenas em dois parágrafos, nos quais ele assume o ponto de vista do realismo sociológico em que o direito é reduzido a conjuntos de decisões tomadas por funcionários e juízes, que podem ser mais ou menos conformes aos princípios do estado de direito.

\footnotetext{
${ }^{7}$ Adotamos essa tradução do termo em inglês porque é a expressão consagrada em português e não vamos explorar neste artigo a variedade de significados de termos equivalentes em diferentes línguas, dadas as tradições jurídicas e trajetórias políticas dos diferentes países (COSTA e ZOLO, 2006; HEUSCHLING, 2002; CHEVALIER, 2003).
} 
“...o fato é que não existe literalmente algo como "o estado de direito". O que existe na realidade são decisões tomadas por funcionários legalmente autorizados que se deparam com situações muitas vezes suscetíveis de diferentes interpretações legais e/ou fáticas, ou juízes que não desejam aplicar de maneira consistente ou equitativa a lei existente, e/ou são socialmente parciais, e/ou têm concepções legais que estão distantes dos princípios ou valores democráticos básicos" (O'DONNELL, 2011, p. 132).

Isso se dá porque a produção do direito é impregnada de relações de poder e, portanto, as lutas políticas e sociais se desenrolam em seus vários momentos, desde o processo de criação das normas legais até a sua interpretação e aplicação. Ao mesmo tempo, acontece que as regras produzem efeitos normativos mesmo depois que as relações de poder desapareceram, continuando as lutas para ressignifica-las e dirigi-las para fins específicos (id., p. 133).

Então, há um campo de relações de poder na (re)produção de normas, campo que é mais ou menos permeável às forças democratizadoras e aos princípios do estado de direito, e que gera efeitos mais ou menos favoráveis à efetividade dos direitos de cidadania e à democratização da burocracia estatal.

\section{Objeção e questões}

A partir dos anos noventa, O’Donnell trata de forma recorrente a questão do (não) estado de direito na América Latina e sua relevância para a democracia. Ele abre um espaço de reflexão e análise sobre essas relações, mas o elabora apenas do ponto de vista da democratização, pois, apesar de apontar as fragilidades e obstáculos do estado de direito, dá apenas algumas indicações sobre o que seria o sistema jurídico, tradição ou a forma de legalidade que aqui se conformou. Ele afirma, em várias ocasiões, que caberia a estudos inter ou transdisciplinares ou ao campo da sociologia jurídica fazer a análise dessas questões (O'DONNELL, 1999, p. 315, n. 51; 2011, p. 115, n. 1). Apresenta-se a seguir uma objeção geral e se formulam algumas questões a contracorrente de suas análises, de modo a explicitar em seguida a maneira pela qual propomos abordá-las.

A objeção geral é a de que o autor adota uma noção de estado de direito formal equiparado a uma legalidade de base democrática, cujas regras conformam um sistema completo, abrangente e igualitário. Mas essa é uma representação do direito elaborada pela teoria política e jurídica e tem limitada correspondência com o "direito" vigente e praticado em qualquer sociedade. Além disso, a validação das normas legais pelo processo democrático, as suas qualidades formais e a sua implementação por burocracias isentas e controladas são insuficientes para pensar as relações entre estado de direito e autonomia dos cidadãos em nossas sociedades. Assim, é preciso pensar o estado de direito não só enquanto legalidade democrática efetiva, mas nas suas relações com a produção normativa na sociedade. Esse ponto será retomado na próxima seção.

O 'Donnell argumenta que nas democracias do "Noroeste" houve a expansão e institucionalização dos direitos civis num processo de longo prazo antes de haver a ampliação dos direitos de cidadania política no final do século XIX. A experiência histórica das democracias na América Latina (e de outras regiões) seria a de ampliação prévia, ou pelo menos concomitante, dos direitos de cidadania política em relação aos direitos civis durante os processos de democratização nos anos 80 do século XX. Mas a ampliação parcial de direitos políticos sem a efetividade de direitos civis ocorreu na América Latina em períodos anteriores e remonta à Independência. Quais seriam as características do direito ou tradição jurídica nos países latino americanos no longo período entre a criação dos Estados liberais-oligárquicos na época da Independência e a democratização? Outro ponto é que o autor vê a fragilidade dos direitos civis da maior parte da população basicamente como resultado da falta de efetividade em virtude dos fatores citados acima. Mas, ao mesmo tempo, ele aponta invenções conceituais, leis ou regras casuísticas de burocratas 
arbitrários (incluídos os juízes) que as aplicam de forma enviesada. Além do efeito de falta de efetividade dos direitos, como pensar esses materiais jurídicos e suas relações com o estado de direito?

Enfim, ele discute as relações entre democracia e estado de direito a partir das qualidades formais do sistema jurídico, em que a diferença entre democracias do Noroeste e da América Latina seria questão de grau de efetividade. Se ele apontou que em nenhum lugar as práticas jurídicas e as condições da cidadania correspondem àquelas qualidades, ele deixou em aberto como pesquisar empiricamente o problema. De todo modo, ele discute o estado de direito em função de dois pontos relacionados: a institucionalização de um sistema de direito positivo igualitário e não arbitrário (entre outros atributos) que o Estado tem a capacidade de assegurar em todo o território e âmbitos de atividade social; e a mediação das relações sociais por essa legalidade de modo a que ela seja assegurada para todos - ou grande parte - dos agentes que nela vivem. Nos dois sentidos o ponto central é o de que seja reconhecida legalmente e assegurada de forma efetiva a capacidade de agência dos indivíduos. Assim, o direito aparece sob dois aspectos: a legalidade estatal e a sua efetividade nas relações sociais. Quais as outras dimensões e qualidades do direito devem ser pensadas nesse espaço entre legalidade e efetividade?

Em suma, o tema do não-estado de direito teve, para O'Donnell, por um lado, o papel de especificação empírica de um determinado conjunto de "casos" de democracias que combinavam regimes políticos eleitorais crescentemente competitivos e precária efetividade dos direitos civis e, por outro lado, o papel crítico que o levou a ampliar o conceito analítico de democracia. Ao assumir o universal reconhecimento da capacidade de agência como característica distintiva da formação das democracias ocidentais que serviu como base de sustentação do estado de direito na sociedade civil, ele adotou a titularidade dos direitos do sujeito tendo como referência a tradição formada na Europa a partir do Iluminismo. Mas ele não discutiu a maneira pela qual o reconhecimento dos direitos civis se incorporou na formação do direito europeu, de um ponto de vista histórico e sociológico. Para os objetivos teóricos de $\mathrm{O}$ 'Donnell, o ponto não seria especialmente problemático, não só porque esse não era o seu propósito, mas também porque há extensa produção sobre o tema. Mas sua discussão para a ampliação do conceito de democracia abriu, como que em contraponto, a questão: como pensar as características do conjunto de agregados jurídicos do (não) estado de direito na América Latina, enquanto a formação histórica, em uma situação de reconhecimento legal (pleno, condicionado ou excepcional) de direitos e a sua não efetividade?

Assim, colocam-se as questões: como pensar os materiais jurídicos que se formam nessa situação de (não) estado de direito? Quais são as características dos saberes jurídicos aqui construídos? Como se formou e se modifica uma tradição de pensamento jurídico de (não) estado de direito, com seus conceitos, doutrinas, técnicas e argumentos? Quais suas características, limites etc.? Não responderemos essas questões neste artigo, mas vamos apresentar algumas dimensões para a análise que se colocam nas interfaces de pesquisas sociológico-políticas, de história do pensamento jurídico e de estudos sócio-jurídicos. O foco analítico do tema da nebulosa de imunidades é propor a pesquisa dos atributos positivos do (não) estado de direito da América Latina, pensado em suas relações com os agregados jurídicos, em particular o pensamento e os saberes que se produzem pela prática jurídica, e a partir dela.

\section{2- Estado de direito e legalidade nos agregados jurídicos}

O'Donnell define o estado de direito como um ideal político ou horizonte normativo que produz efeitos bastante reais, mas com graus diferentes de realização histórica ou de efetividade. Essa efetividade se realizaria pela série: direitos como reconhecimento da capacidade de agência, ideal do estado de direito, sistema legal, capacidade do Estado de regular as relações sociais e a ordem legal como expectativas normativas compartilhadas. 
Uma forma distinta de pensar a relação entre as idealizações, a construção de relações objetivas e as identidades, expectativas e comportamentos é pensar aquele ideal político como forma de problematização das relações de governo e de aquiescência/resistência da multiplicidade na sociedade (FOUCAULT, 1984, p. 15; 2004, p. 4). Essas relações se dão como um campo estratégico de interações e se realizam com a observação, programação e reflexão sobre a maneira de conduzir a si e aos outros de modo a compor o conjunto de possibilidades de ação de uns e outros. Nesses termos, o estado de direito é o nome dado para a problematização da programação jurídica e normativa das condutas que visa racionalizar e programar o seu exercício, em função de certos princípios, com determinado campo de exercício, procedimentos e objetivos. Instauram-se certas instâncias de produção de discursos em que determinados sujeitos são autorizados a falar em seu nome, utilizar seus instrumentos, e visar certos efeitos. Em outros termos, o estado de direito enquanto maneira de problematizar está presente em vários lugares, mas suas singularidades e formas positivas são relativas à dinâmica do exercício e das formas de resistência ao governo. A variedade histórica do estado de direito aparece nas suas construções efetivas nas sociedades, cujas diferenças não são pensadas em função de graus de efetivação, mas de suas próprias condições e trajetória.

O propósito comparativo torna-se menos colocar numa escala organizada em função de um ideal e mais entender essas singularidades na sua trajetória própria em seu contexto e condições. As relações do estado de direito com a legalidade, práticas jurídicas e relações sociais não se pensam como um jogo unidimensional entre o vetor do estado de direito, que visa a efetivação de princípios de liberdade, igualdade, tratamento equitativo etc., e outros vetores que atuam em sentido contrário, e que são sustentados por chefes locais, interesses privados ou concepções patrimonialistas que se assentam em relações sociais desiguais. As relações são um jogo multidimensional, em que competem diferentes saberes e relações de poder, que são internos e externos ao Estado. A dimensão do estado de direito se apresenta como uma força em relação a outras formas de exercício do poder, tradições, interesses etc., mas também como forma de reflexão e objeto de disputas entre diferentes projetos político-constitucionais.

O "direito" de determinada sociedade, do ponto de vista de suas manifestações concretas, não corresponde à imagem de unidade, completude e autonomia do ordenamento legal, e tampouco é um compacto fechado de lógica, coerência e justiça que pode ser instrumentalizada por sujeitos que podem desviá-lo do seu objetivo final. Ele é melhor entendido como uma combinação de "agregados jurídicos" (juridical assemblages) compostos por saberes, agentes autorizados, instituições, técnicas e arranjos formais e informais. Eles se compõem de subconjuntos e camadas distintas, criados segundo modelos e em momentos diferentes, que assumem formas mais ou menos aproximadas aos seus modelos formais ou originários e que produzem efeitos mais ou menos relevantes ${ }^{8}$ (HUNT, 2013). O grau de integração e coerência desses agregados jurídicos é sempre imperfeito, diversificado, permeado de tensões e contradições, conformando composições distintas em diferentes épocas.

O termo "agregados jurídicos" designa um campo em que se exerce determinado poder simbólico, uma esfera diferenciada de relações sociais em que se disputa o controle de determinados recursos ou uma instância de enunciação de discursos dotados de autoridade. São compostos, mais ou menos coerentes, com suas camadas variadas e diferenciações internas e combinações de legalidades e ilegalidades toleradas. Os agregados jurídicos compreendem diversas dimensões, já trabalhados em estudos sócio-jurídicos internacionais e brasileiros: seus arranjos institucionais, seus agentes, a sua conformação como campo ou esfera diferenciada, como um espaço de lutas com poder diferencial das frações de classe, como um tipo de saber produzido sobre o direito, como formador de "sensibilidades".

${ }^{8}$ O'Donnell afirma este ponto, mas não o elabora (2011: 130). 
A análise dos arranjos institucionais tem em vista as regras, os atores, interesses e as formas e oportunidades de ação no conjunto de agregados jurídicos. Por elas se conhece a maneira pela qual se organizam os diferentes papéis institucionais; os seus atributos, recursos e posições relativos; as suas identidades e estruturação das carreiras e hierarquias internas; a sua abertura ou insulamento em relação a outras instituições ou atores estatais e sociais. Essa abordagem é a mais disseminada em ciência política internacional (GILMANN e CLAYTON, 1999) e resultou no Brasil em inúmeras pesquisas sobre as instituições judiciais (ARANTES, 1997 e 2002; KERCHE, 2007; KOERNER e FREITAS, 2013; MACIEL e KOERNER, 2014). Uma temática importante é o das relações entre campo jurídico e políticas públicas, em que se pesquisa como as instituições e atores judiciais acolhem, resistem, conformam ou reconfiguram as políticas estatais em diversos campos. Um tema particularmente discutido foi o da "judicialização das políticas de saúde" em que as pesquisas mostraram inicialmente a passagem do não acolhimento das demandas à intervenção voluntarista dos juristas e juízes, seguida da cooperação entre atores e instituições que levaram a novos arranjos institucionais e políticas coordenadas (FANTI, 2010; OLIVEIRA, 2015; WANG, 2014). Em questões de caráter estrutural, como conflitos fundiários e trabalho escravo, a tendência é que as políticas governamentais para a efetivação dos direitos encontrem divisões e resistências nas instituições judiciais, que levam à neutralização ou minimização da realização dos objetivos visados por aquelas políticas (INATOMI, 2016). O mesmo parece acontecer, mas em menor grau, com políticas que produzem a precarização dos direitos, que encontram divisões e resistências nas instituições judiciais, mas tendem a prevalecer.

Quanto aos atores, pesquisas no campo das elites jurídicas examinaram os seus perfis, origem familiar, formas de seleção, hierarquias internas e relações de gênero (BONNELLI, 2002 e 2008; SADEK, 1998; VIANNA, 1997). A esse respeito, colocam-se o tema do perfil tradicional da elite jurídica e demais trabalhadores no campo em contraste com as novas configurações das profissões jurídicas resultantes da internacionalização das profissões, da organização de grandes corporações, da massificação do ensino jurídico e dos efeitos das chamadas "indústrias de concursos" (ENGELMANN, 2011 e 2017; FONTAINHA et al, 2018; ALMEIDA, 2010 e 2016; CUNHA, 2007).

O poder simbólico do campo do direito refere-se ao monopólio dos juristas do direito de dizer o direito, isto é, a boa distribuição (nomos) ou a boa ordem da sociedade. Esses agentes têm determinados atributos de ingresso no campo diferenciado, ao mesmo tempo em que estão em constante disputa por aquele poder, detendo posições e capacidades diferenciadas (BOURDIEU, 1986, p. 4). No Brasil, foram apontadas as especificidades da trajetória histórica e do modo de diferenciação do campo do direito em relação ao campo do poder estatal, em particular que as posições dominantes no campo do direito não são ocupadas segundo uma lógica interna, uma vez que a disputa por elas é perpassada por relações dos juristas com o campo do poder. Além disso, a lógica de dizer o direito não é determinada apenas por categorias e regras internas ao campo, pois nelas se expressam conteúdos materiais e objetivos pontuais que se entrelaçam as lógicas de outros campos (ENGELMANN, 2011 e 2017; VANNUCCHI, 2016a e 2016b).

O poder social dos juristas relaciona-se ao tema da produção do direito enquanto parte de um conjunto de lutas e alianças entre frações de classe para a elaboração de um discurso hegemônico sobre a ordem da sociedade. O direito não é um fenômeno unitário que pode ser "deduzido" dos interesses ou das posições de classe e assim a análise política do direito demanda a avaliação das possibilidades em cada campo legal e situação específica relacionando com a sustentação da dominação de classe na sociedade em geral (HUNT, 1993, p. 90-1). Coloca-se em especial a questão de como a produção do direito pelos juristas é mais ou menos aberta às demandas, pressões e formas de mobilização de grupos sociais subordinados ou discriminados. A produção do direito pode definir ou obscurecer categorias sociais, pode estabilizar ou desestabilizar expectativas sociais, pode manter ou minar normas sociais de convivência; e fortalecer ou enfraquecer consensos sociais, assim como pode aliviar ou exacerbar tensões sociais (MACAULAY, 1987). 
Os efeitos simbólicos da legislação relacionam-se com a temática mais geral do direito nas relações sociais. Aqueles efeitos são designados como o poder constitutivo dos saberes e práticas jurídicas com os quais se configura nas relações sociais numa trama objetiva de normas que são tomadas como dadas pelos agentes e assim estruturam a sua autocompreensão normativa, orientações de ação e expectativas (BRIGHAM, 1996; HUNT, 1993, p. 252; MERTZ, 1994). A estruturação se dá por conhecimentos, relações e processos localizados, através do modo pelo qual os agentes imaginam, entendem e agem no mundo social (GEERTZ, 1983). Mas os direitos legalmente reconhecidos são resultado e objeto de lutas sociais, que se passam em processos de mobilização e contra-mobilização política, podendo ser tanto instrumentos de resistência quanto de dominação (MERRY, 1995; SILBEY, 2005). A demanda por direitos, pela ressignificação daqueles já reconhecidos ou por ações estatais que os tornem efetivos, supõe a articulação de discursos públicos, com fundamentos, táticas e proposições explícitas com as quais os agentes conformam e reconfiguram suas identidades individuais e coletivas como cidadãos (HUNT, 1993, p. 107; MCCANN, 2006 e 2010; MACIEL, 2011 e 2015).

Sobre os saberes jurídicos, discutiu-se nos anos oitenta e noventa os efeitos de poder da dogmática jurídica a partir da epistemologia, a crítica da ideologia e a semiologia do poder (COELHO, 1991; MIAILLE, 2005; WARAT, 1995). A dogmática jurídica elabora construções abstratas que atribuem unidade, coerência e certeza a noções jurídicas, que têm o caráter de saberes que organizam conceitualmente o exercício do poder estatal e a exploração capitalista. Eles legitimam essas relações pela sua posição de fala competente, pela naturalização das relações sociais, a justificação dos arranjos existentes e a formação conformista dos juristas. Ao mesmo tempo, ocultam e invertem as relações de poder e exploração, assim como as lutas de poder que perpassam a prática do direito. As noções de norma jurídica e de sistema ou ordenamento são centrais nessas construções, uma vez que a primeira é tomada como um dado e é integrada num conjunto que lhe dá coerência e unidade.

Um tema pouco pesquisado pelos estudos sócio-jurídicos no Brasil é como os juristas exercem a sua fala especializada sobre o direito. O seu ethos, os procedimentos, técnicas e estilos das suas decisões, assim como a eles leem, articulam conceitos, elaboram argumentos, formulam suas interpretações das leis, abordam as situações e constroem os casos (CARBASSE E DEPAMBOUR-TARRIDE, 2010; GARAPON E PAPADOPOULOS, 2003; GOLDSWORTHY, 2006; JACOB, 1996; MACCORMICK e SUMMERS, 1991 E 1997). A pesquisa comparada permite conhecer a prática jurídica brasileira para além de oposições simples como autocontenção e ativismo dos juízes ou o sistema de fontes do direito das tradições do civil law e do common law (MENDES, 2010). Tem-se aqui dois desdobramentos importantes, por um lado, a incorporação da autocompreensão normativa e das "sensibilidades" dos leigos ao direito praticado pelos juristas. Complementarmente, como os cidadãos se relacionam com o direito estatal, como identificam suas oportunidades e recursos, e como relacionam a legalidade estatal e aquilo que consideram certo ou errado segundo uma 'boa' construção da ordem do mundo, da vida, da sociedade (LIMA, R.K., 2009). Por outro lado, como se constitui o habitus ou o ethos dos juristas na sua condição de agentes dotados de saberes e recursos de poder próprios em seu próprio campo especializado, em suas relações com o campo do poder estatal e, enfim, como um setor diferenciado da população, possuidor de um saber letrado e com capacidade de provocar efeitos próprios na direção das condutas dos demais agentes. Uma temática de pesquisas em que se discute essas questões é a do acesso à justiça, onde são inúmeras e antigas as constatações das disputas entre juristas e as dissonâncias entre os critérios e objetivos das instituições judiciais com as expectativas e auto-compreensão normativa dos cidadãos (GARCIA, 2018; INATOMI, 2009; MOREIRA-LEITE, 2003). 
Em suma, se o estado de direito enquanto sistema legal formal e completo não se realiza em parte alguma, não se trata apenas de diferenças de grau de sua efetividade. As diferenças referem-se ao conjunto de "agregados jurídicos", à maneira pela qual eles se constituíram historicamente e se exercem na atualidade, em suas relações com o poder estatal e as relações sociais. Nesse sentido, os agregados podem ser analisados como regimes formados por configurações historicamente constituídas da instância, do setor ou do campo jurídico em cada país ou sociedade

\section{3- Nebulosa de imunidades?}

Voltemos à definição de estado de direito adotada por O 'Donnell. É uma definição formal, formulada por Joseph Raz (1977) $)^{9}$, que enumera oito características, divididas em duas partes: a que compreende as três primeiras e se refere aos atributos das leis e a que diz respeito aos tribunais e critérios da sua prática. As características 5, 6 e 8 não se relacionam a atributos das normas ou das instituições, mas à maneira pela qual as normas são efetivadas para que aqueles atributos sejam preservados. A de alcance mais amplo é o controle judicial para que as regras de reconhecimento e aplicação das leis sejam gerais e prospectivas, claras para que se evitem arbitrariedades. Raz assume um ponto de vista prático, o da autoridade das leis para que os indivíduos as obedeçam, cuja condição é que elas façam sentido para eles. O direito é uma forma de organização que deve ser usada de forma apropriada para guiar as condutas dos indivíduos, enquanto, para estes, a lei deve ser capaz de guiar o seu comportamento, se ela é para ser obedecida. Assim, as características do estado de direito enfocam tanto os atributos de leis e instituições quanto à maneira de exercê-los. Exploramos esses aspectos em dois pontos: as relações entre o ideal do estado de direito, as características formais das regras e sua efetivação e as consequências para o estado de direito da maneira pela qual as regras são praticadas pelos juristas.

O estado de direito é usualmente definido como um ideal normativo do "governo das leis" oposto ao governo dos homens. Em geral, adotam-se como critérios a forma das regras e ao modo de produzi-las. Disso resultam os critérios citados da generalidade, da anterioridade e da estabilidade, e que sejam elaboradas por procedimentos públicos, tendo em vista os interesses comuns, que respeitem um rol de direitos e que sejam formadas por processos de deliberação coletiva democrática. Em contraposição, o governo dos homens seria exercido por ordens ou comandos produzidos pelos governantes segundo sua deliberação individual ou arbítrio, e que podem ter objetos particulares, situações específicas ou serem posteriores aos eventos, podem visar interesses privados (ou definidos privadamente como interesses comuns).

O ideal normativo do estado de direito permite assumir uma perspectiva de observação e avaliação das situações concretas. Avalia-se a qualidade das leis e como elas se traduzem em formas jurídicas ou institutos. A ausência daquelas leis e formas jurídicas seria um estado de não-direito ou governo dos homens. Há várias situações intermediárias, tais como o exercício do poder arbitrário ou tirânico em violação às leis; o governo autocrático por meio de leis gerais, claras e estáveis (rule by law), o Estado que se vale de leis gerais para alcançar seus objetivos

\footnotetext{
${ }^{9}$ As características são: 1 . As leis devem ser prospectivas, públicas e claras; 2 . As leis devem ser relativamente estáveis; 3. A confecção de leis específicas deve orientar-se por regras gerais públicas, estáveis e claras; 4 . A independência do poder judiciário deve ser garantida; 5. Deve observar-se os princípios da justiça natural (tais como audiências judiciais abertas e equitativas e a ausência de viés nos processos); 6 . Os tribunais devem ter poderes de revisão [...] sobre a implementação dos outros princípios; 7. Os tribunais devem ser facilmente acessíveis; e 8. Não se deve permitir que as instituições de prevenção de delito valham-se de sua discricionariedade para perverter a lei (RAZ, 1977, p. 198-201, e O'DONNELL, 2011, p. 117).
} 
(estado legal); o estado de polícia em que o governo usa normas regulamentares sem respeitar a forma nem os direitos dos cidadãos ${ }^{10}$.

Do ponto de vista da efetividade, haveria uma série de situações entre dois polos opostos, o primeiro em que o ideal do estado de direito se realiza nitidamente porque se traduz de maneira clara na legislação, nas práticas e saberes jurídicos e nas relações sociais e o segundo em que, pelo contrário, aquele ideal é contrariado e não se visualizam quaisquer efeitos. Seriam "constelações" contrastadas com "buracos negros". O (não) estado de direito de O'Donnell designa um conjunto de casos intermediários de realização incompleta ou de baixa efetividade. São, com vimos, situações em que o ideal normativo tem pouca força, a burocracia estatal tem baixa eficácia e a legalidade estatal é deficiente, tem baixa efetividade na regulação da sociedade e tem baixa objetividade na ordenação das interações sociais dos indivíduos. Mas, como afirmamos na seção anterior, para analisar essas situações intermediárias, é preciso considerar o direito de um ponto de vista sociológico que leve em conta outras dimensões além da efetividade da legalidade estatal.

O segundo ponto indicado no início da seção refere-se aos efeitos da prática jurídica para o estado de direito. Colocamos a seguinte questão: o que acontece se tribunais dotados de independência (4.), que utilizam (pelo menos em parte) os procedimentos de justiça natural nos seus julgamentos (5.) e têm poderes de controle das leis e outras ordens governamentais (6.) interpretam as leis (com apoio na doutrina jurídica) de modo que não se realizem as características do estado de direito relativas às leis (1. e 2.) ou que sejam contrariados os atributos gerais das leis e os critérios para a sua aplicação (6. e 8.)? Do ponto de vista de Raz, estaríamos diante da não conformidade com o estado de direito e da desobrigação dos indivíduos de obedecê-las.

Para O'Donnell a situação seria um caso de (não) estado de direito. Ele cogita a possibilidade e a atribui a fatores como a falta de adesão dos juízes aos princípios democráticos, aos interesses particulares dos juízes ou juristas, a pressões externas etc., e que resultam na não efetividade das leis nas interações sociais (O'DONNELL, 2011;: 117-8). Sem dúvida, mas pode haver desvios do estado de direito, provocados não necessariamente pela não adesão dos juristas aos princípios do estado de direito, nem de efeitos de orientações particularistas e contrárias ao interesse público, nem sequer de falta de condições institucionais ou sociais para a decisão independente ou tecnicamente informada. Voltando a uma questão posta anteriormente, se as democracias latino-americanas conhecem uma passagem abrupta à democracia baseada numa noção ampla de agência e que implica a generalização do estado de direito, quais seriam as características da "tradição jurídica" que se formou nos duzentos anos desde a Independência? Qual é a conformação positiva do pensamento que refletiu e programou os saberes nos agregados jurídicos?

Trata-se, então, de pesquisar o pensamento e saberes jurídicos, ou seja os princípios, conceitos, critérios e técnicas de julgamento elaborados pelos juristas que não produzem os atributos de clareza e estabilidade das leis (1. e 2.) e que produzem normas para si próprios sem essas características (3.). As construções dos juristas reconhecem e defendem parcialmente as características do estado de direito, que, combinadas, contrariam ou inibem seu efeito geral. Nesses termos, sugere-se a hipótese de que o pensamento jurídico realiza uma maneira de problematizar o estado de direito em que reflete e programa os saberes jurídicos de forma que eles reproduzem interpretações particularistas das regras, reforçam a ineficácia das burocracias estatais, ampliam a inefetividade do direito estatal na regulação e aprofundam a sua baixa objetividade na ordenação das condutas dos indivíduos nas suas interações sociais. Coloca-se, assim, a proposta de pesquisar aspectos do pensamento e saberes jurídicos brasileiros que revelem essas ambivalências, intransparências e incertezas.

\footnotetext{
${ }^{10}$ Outros critérios seriam o padrão de referência da norma (o direito natural, as liberdades, históricas...), a relação com os destinatários, a extensão dos direitos) (COSTA e ZOLO, 2006; DIAZ, 1972; TAMANAHA, 2004).
} 
A partir da discussão desses dois pontos, temos que a experiência jurídica brasileira é uma das situações históricas intermediárias em que o ideal do estado de direito se realiza de modo parcial e muito diferenciado. Nela se integra um conjunto de agregados jurídicos que assumem conformações variadas segundo as subáreas do direito, espaços territoriais e domínios de relações sociais e campos de relações de poder. Essas realizações diferenciais são produzidas pelos juristas e reforçadas pela maneira de eles refletirem e programarem os seus saberes e práticas. Para o observador, as relações entre ideal normativo, legalidade estatal e relações sociais apresentam-se com graus distintos de nitidez e certeza à medida em que dirige o seu olhar em direções diferentes. Sugerimos que esse jogo entre o estado de direito, suas realizações e seus múltiplos contrários configura uma "nebulosa de imunidades".

Segundo o dicionário Aurélio, nebulosa é o feminino de 'nebuloso': o que é 1 . coberto de nuvens ou vapores densos; 2. Sombrio, triste, ameaçador, nublado, nubiloso, nuvioso; 3. Sem transparência, turvo; 4. Pouco definido, indistinto; 5. Ininteligível, obscuro, enigmático, misterioso, nevoento. Como substantivo, nebulosa também significa 1. Corpo celeste que se apresenta com o aspecto de mancha esbranquiçada; 3. Massa estelar ainda em via de condensação; 3 . Universo em formação.

'Imunidade' significa: 1. Condição de não ser sujeito a algum ônus ou encargo, isenção; 2. Resistência natural ou adquirida de um organismo vivo a um agente infeccioso ou tóxico; 3 . Direitos, privilégios ou vantagens pessoais de que alguém desfruta por causa do cargo ou função que exerce.

Tal como o conceito de estado, o termo 'nebulosa' refere-se a uma situação estável, caracterizada por certos atributos e relações, mas, ao contrário das propriedades "arquitetônicas" do estado de direito, elas são pouco discerníveis para o observador, embora sejam bem conhecidas e praticadas pelos agentes. Num sentido sócio-jurídico, a nebulosa designa o conjunto de espaços organizados com geometria variável, em que as normas jurídicas estatais são perpassadas por outras normatividades e lógicas sociais, e em que o poder estatal e poderes sociais se combinam na produção do direito e no uso da força. Eles se exercem de forma diferenciada em função da condição dos agentes, determinada pela cor, gênero, orientação sexual, renda ou atividade ocupacional e vínculos com os proprietários da terra.

A titularidade de direitos está associada à condição de agente ou de nacional, ou a capacidades de categorias gerais de indivíduos (ou de coletividades). A titularidade de direitos tem obrigações como seus correlatos, em particular o reconhecimento dos direitos dos outros cidadãos, e deveres para com o público e o Estado. Por sua vez, as imunidades não implicam o reconhecimento das obrigações face aos outros ou de seus direitos, porque são unilaterais, recebidas ou exercidas por isenção, exceção ou privilégio em relação a normas gerais. Elas significam a proteção particularizada contra violações, incertezas e riscos que podem acometer os demais agentes ou serem ocasionadas por eles. A proteção de direitos subjetivos realizada pelo Judiciário assume o caráter de concessão (ou rejeição) de imunidades, pois seus julgamentos produzem normas sempre particularizadas e incertas, que é incapaz de produzir referências gerais e dotadas de objetividade para os agentes. Tem-se então uma situação de proteções particularizadas, privilegiadas e sem reciprocidades para alguns, cujo contraponto são violações, privações e pobreza para outros.

A noção de "nebulosa de imunidades" coloca-se quando, para o observador, há pouca nitidez sobre as relações entre o ideal do estado de direito, os agregados jurídicos e as relações sociais. É uma situação que, em seu conjunto, é pouco discernível, pois apresenta aglomerados luminosos de imunidades de maior ou menor grandeza, mas também vazios ou escuros em que as proteções não se realizam. Ela designa uma situação social permanente (ou em lenta mudança), cujos elementos se mantêm e relacionam de modo estável. Ela leva em conta não apenas o ponto de vista das regras estatais e da sua efetividade, mas 
a maneira de se pensar e de se praticar o conjunto de agregados jurídicos e seus efeitos na sociedade. $O$ ideal do estado de direito está presente nos aspectos formais da arquitetura jurídico-constitucional do Estado, atualiza-se em alguma medida na sua legalidade, burocracias e declarações de direitos. Mas esses elementos gerais são refratados pelos saberes e práticas jurídicos dos agregados, o que resulta que as regras e as formas perdem os seus atributos de generalidade, clareza etc. e elas configuram uma trama objetiva que combina privilégios e violações que os agentes assumem nas suas interações. Particularismo e violações, desigualdade e não-reciprocidade complementam-se, na medida em que as relações entre cada um e os demais são perpassadas por normas pouco claras. Desse modo, é essa combinação, e não os princípios gerais, normas legais ou discursos doutrinários, que aparece para os agentes como o direito assegurado pelo Estado, como a ordem que se põe como norma objetiva e que eles tomam como dada em suas interações.

Assim, nebulosa de imunidades refere-se a esse efeito de ótica produzido pela conformação dos agregados jurídicos e suas consequências para as práticas sociais. A noção não tem pretensão analítica ou descritiva, e serve apenas para colocar a questão de como se (re)produz tal situação e discutir criticamente os fatores que a produzem, pois apesar de pouco nítida, ela é uma situação social determinada por fatores conhecíveis, que pode ser analisada e explicada. Ela convida a não pensar norma e fato, legalidade e arbítrio, conformidade e violação da lei, privilégio e exclusão em termos contrapostos mas procurar entender as suas combinações. Pensar o caráter diferencial da efetividade dos direitos não em termos de formas institucionais, como eventos discretos ou efeitos de estrutura social, mas como resultado das práticas jurídicas e das relações de poder que se dão numa determinada configuração social e histórica. A incompatibilidade de termos jurídicos e conceitos sociológicos é um obstáculo conhecido para quem pesquisa o direito do ponto de vista das práticas jurídicas e normatividades sociais. Por isso, é necessário, assumir uma perspectiva e elaborar um vocabulário próprio.

Os diversos significados da noção servem também para indicar o problema de pesquisa-la e analisa-la, uma vez que, à medida em que nos aproximamos da nebulosa, ela deixa de ser uma espécie de espetáculo de luzes e sombras para se tornar um nevoeiro dentro do qual temos poucas referências para nos orientarmos. Enquanto cidadãos e pesquisadores nos vemos diante de uma trama de situações com dimensões normativas e situações concretas tensas e contraditórias, com as quais temos que lidar praticamente. Há guias que podem nos levar a pontos turísticos, com paisagens mais ou menos agradáveis, mas nelas teremos apenas a visão parcial de coisas arranjadas.

\section{Conclusão}

O artigo não questionou as análises de $\mathrm{O}^{\prime}$ Donnell sobre as relações internas entre democracia e estado de direito nem argumentou contra a sua preocupação com as especificidades das democracias latinoamericanas. Também não foram postas em discussão as teses sobre a extensão do estado de direito como o reconhecimento universal da capacidade de agência, a de que ninguém é legibus solutus e que a democracia abre espaço para a participação ampliada dos grupos sociais na produção da norma e a sua contestação. O que se questionou foi a sua análise das relações entre estado de direito formal, sistema legal e o problema da sua efetividade na sociedade. A discussão apontou para a necessidade de se assumir um ponto de vista sócio-jurídico para analisar o direito em suas diversas dimensões e para um enfoque especial as relações entre pensamento jurídico e práticas jurídicas, visando uma reflexão centrada na produção dos saberes jurídicos. 
Pode haver - e há - uma tradição jurídica que se reproduz por saberes jurídicos que não realizam os atributos do estado de direito, e o faz em seu próprio nome. Essa atuação não é necessariamente o objetivo de atores que visam interesses particulares ou têm propósitos irrefletidos e nem efeito direto de pressões "externas" pela aplicação particularista ou distorções intencionais das normas. É um efeito geral e coletivo, "sistêmico", produzido pela sua maneira de problematizar os agregados jurídicos. Essa produção gera crises que podem levar a paralisias e atitudes "heroicas", mas não saem do impasse, reproduzindo as ambiguidades e incertezas da nebulosa de imunidades.

Nossa discussão abriu a “caixa de Pandora” conceitual que O'Donnell tanto queria evitar. Ela nos distancia da parcimônia preconizada pelas teorias de política comparada de se adotarem poucos critérios objetivos para identificar e pesquisar as democracias. Mas os aspectos dos agregados jurídicos destacados servem como dimensões analíticas para pesquisas sócio-jurídicas e de ciência política que integrem as dimensões da democracia e do direito em estudos sobre países singulares, e poderão servir como base para análises comparadas.

A discussão sobre a nebulosa de imunidades propõe a análise política do pensamento jurídico para realizar a crítica teórica e historicamente informada dos saberes jurídicos na sociedade brasileira. Não se trata de um argumento genético do tipo "males de origem" e nem um argumento continuísta, muito menos a atribuição dos males da república a uma elite de juristas. Não se visa realizar uma síntese sobre "direito e sociedade no Brasil" ou o pensamento jurídico no capitalismo periférico. O tema do estado de direito é estratégico pois a sua especificidade permite análises em períodos históricos longos, é central, pois ele se dissemina em uma diversidade de campos de saberes e práticas jurídicas e, enfim, é crítico, pois com ele o pensamento jurídico se coloca como problematização, como distanciamento e reflexão, sobre aqueles saberes e práticas. O trabalho intelectual começa com o questionamento da maneira pela qual o pensamento jurídico programa o governo de nossas condutas pelo direito, colocando-lhes a questão dos seus efeitos improfícuos para a democracia e a cidadania no Brasil.

\section{Bibliografia}

ALMEIDA, F. 2010. A nobreza togada: as elites jurídicas e a política da Justiça no Brasil. São Paulo. Tese (doutorado em ciência política). PPGCP/USP, Universidade de São Paulo.

2016. Os Juristas e a Política no Brasil: Permanências e Reposicionamentos. Lua Nova, São Paulo, n. 97, pp. 213-252, jan-abr.

ARANTES, R. B. 1997. Judiciário e política no Brasil. São Paulo: Sumaré/FAPESP.

2002. Ministério Público e Política no Brasil. São Paulo: Sumaré.

BONELLI, M.G. et al. 2002. Profissionalismo e politica no mundo do direito: as relações dos advogados, desembargadores, procuradores de justiça e delegados de polícia com o Estado. São Carlos: EdUFSCar.

2008. Profissionalização por gênero em escritórios paulistas de advocacia. Tempo Social, São Paulo, v. 20, n. 1, pp. 265-290.

BOURDIEU, P. 1986. La Force du Droit (Eléments pour une sociologie du champ juridique). Actes de la Recherche en Sciences Sociales, Paris, v. 64, pp.3-19, setembro.

BRIGHAM, J. 1996. The Constitution of Interests - Beyond the Politics of Rights. New York: New York University Press. 
BRINKS, D. \& BOTERO, S. 2014. Inequality and the Rule of Law: Ineffective Rights in Latin American Democracies. In: Brinks, D. et al (eds.). Reflections on Uneven Democracies: the legacy of Guillermo O’Donnell. Baltimore: John Hopkins UP, pp. 214-239.

BRINKS, D. et al. (eds.). 2014. Reflections on Uneven Democracies: the legacy of Guillermo O'Donnell. Baltimore: John Hopkins UP.

CARBASSE, J.-M. e DEPAMBOUR-TARRIDE (eds.). 2010. A Consciência do Juiz na Tradição Européia. Belo Horizonte: Tempus.

COELHO, L. F. 1991. Teoria Crítica do Direito. Porto Alegre: Sérgio Antônio Fabris.

COSTA, P.; ZOLO, D. (eds.). 2006. O Estado de Direito - História, Teoria, Crítica. São Paulo: Martins Fontes.

CHEVALIER, J. 2003. L'Etat de droit. Paris: Montchrétien.

CULLEL, J. V. 2014. Democracy and Democratization: Guillermo O'Donnell's Late Attempt to Rework Democratic Theory. In: Brinks, D. et al (eds.). Reflections on Uneven Democracies: the legacy of Guillermo O’Donnell. Baltimore: John Hopkins UP, pp. 287-311.

CUNHA, L. G. et al. 2007. Sociedades de advogados e tendências profissionais. Revista Direito GV, São Paulo, v. 3, n. 2, pp. 111-137.

DIAZ, E. 1972. Estado de Direito e Sociedade Democrática. Lisboa: Iniciativas Editoriais.

DOBRY, M. 1992. Sociologie des Crises Politiques. Paris: FNSP.

ENGELMANN, F. 2011. Estudando e definindo elites jurídicas. Paper apresentado no Colóquio Elites História e Método, Porto Alegre: PPG História PUCRS.

(org.). 2017. Sociologia Política das Instituições Judiciais. Porto Alegre: CEGOV/UFRGS ed.

FANTI, F. 2010. Políticas de Saúde em Juízo: um estudo sobre o município de São Paulo. São Paulo, Dissertação (mestrado) PPGCP-FFLCH/USP.

FONTAINHA, F. et al. 2018. Os três poderes da elite jurídica: a trajetória político-partidária dos ministros do STF (1988-2013). Revista de Ciências Sociais, Fortaleza, v.49, n.2, pp.93-131.

FOUCAULT, M. 1984. História da Sexualidade, Vol. 2 - O Uso dos Prazeres. RJ: Graal. 2004. Naissance de la Biopolitique - Cours au Collège de France, 1978-1979. Paris: Gallimard, Seuil. GARAPON, A. e PAPADOPOULOS, I. 2003. Juger en France et en Amérique. Paris: Odile Jacob.

GARCIA, E. P. 2018. "Não cause, concilie": os sentidos da política de conciliação em um Centro Judiciário de Solução de Conflitos e Cidadania em Campinas-SP. Campinas. Dissertação (Mestrado), PPGCP-IFCH/ Unicamp.

GEERTZ, C. 1983. Local Knowledge - Further Essais in Interpretive Anthropology. New York: Basic Books. 
GIBSON, E. 2013. Boundary Control: Subnational Authoritarianism in Federal Democracies. Cambridge: Cambridge UP.

GILLMAN, H. C.; CLAYTON, C. (eds). 1999. Supreme Court in American politics: New Institutionalist Interpretations. Lawrence: University of Kansas Press.

GOLDSWORTHY, J. (ed.). 2006. Interpreting Constitutions - A Comparative Study. Oxford: Oxford UP.

HALL, P. 2015. Politics as a Process Structured in Space and Time. In: Tulia Falleti, Orfeo Fioretos, and Adam Sheingate. The Oxford Handbook of Historical Institutionalism. NY: Oxford UP.

HEUSCHLING, L. 2002. Etat de Droit, Rechtsstaat, Rule of Law. Paris: Dalloz.

HUNT, A. 1993. Explorations in Law and Society - Toward a Constitutive Theory of Law. Londres: Routledge.

. 2013. Encounters with juridical Assemblages: reflections on Foucault, law and the juridical. In: GOLDER, B. (Ed.). Re-reading Foucault: On Law, Power and Rights. Londres: Routledge, pp. 64-84.

INATOMI, C. C. 2009. O Acesso à Justiça no Brasil: a atuação dos Juizados Especiais Federais Cíveis. Campinas. Dissertação (Mestrado). PPGCP-IFCH/Unicamp.

2016. A atuação do Poder Judiciário nas políticas de erradicação do trabalho escravo rural no Brasil contemporâneo. Campinas. Tese (Doutorado). PPGCP-IFCH/Unicamp.

JACOB, R. (ed.). 1996. Le Juge et le Jugement dans les Traditions Juridiques Européenes. Paris: LGDJ.

KERCHE, F. 2007. Autonomia e discricionariedade do Ministério Público no Brasil. DADOS - Revista de Ciências Sociais, Rio de Janeiro, v. 50, n. 2, pp. 259-279.

KOERNER, A. e FREITAS, L. B. 2013. O Supremo na Constituinte e a Constituinte no Supremo. Lua Nova, v. 88, p. 141-85. Disponível em: www.scielo.br/scielo.php?pid=S0102-64452013000100006\&script=sci_arttext

LIMA, R. K. 2010. Sensibilidades jurídicas, saber e poder: bases culturais de alguns aspectos do direito brasileiro em uma perspectiva comparada, [Online]. Anuário Antropológico, II. Disponível em: http://journals. openedition.org/aa/885. Acesso em 23 setembro 2019.

MACAULAY, S. 1987. Images of Law in Everyday Life: The Lessons of School, Entertainment, and Spector Sports. Law \& Society Review, Amherst, v. 21, n. 2, pp. 185-218.

MACIEL, D.A. 2011. Ação coletiva, mobilização do direito e instituições políticas: o caso da campanha da Lei Maria da Penha. Revista Brasileira de Ciências Sociais, São Paulo, v. 26, n. 77, pp. 97-112.

2015. Mobilização de Direitos no Brasil: grupos e repertórios, [Online]. DS/FFLCH/USP. Disponível em: http://sociologia.fflch.usp.br/sites/sociologia.fflch.usp.br/files/Mobiliza\%C3\%A7\%C3\%A3o\%20 de\%20direitos\%20D\%C3\%A9bora\%20A\%20Maciel\%20_\%20LAPS.pdf. Acesso em 20 setembro 2019.

e KOERNER, A. 2014. O processo de reconstrução do Ministério Público na transição política (1974-1985). Revista Debates, v. 8, n. 3, set.-dez., pp. 97-117.

MANN, Mi. 1992. O poder autônomo do Estado: suas origens, mecanismos e resultados. In: HALL, J. (ed.). Os Estados na História. Rio de Janeiro: Imago. 
MARSHALL, T. H. 1950. Citizenship and Social Class and Other Essays. Cambridge: Cambridge UP.

MCCANN, M. 2006. Law and Social Movements: Contemporary Perspectives. Annual Review of Law and Social Sciences, v. 2006, n. 2, pp. 17-38. doi: 10.1146/annurev.lawsocsci.2.081805.105917.

.2010. Poder Judiciário e Mobilização do Direito: uma perspectiva dos 'usuários'. Revista EMARF, Cadernos Temáticos: Seminário Nacional sobre Justiça Constitucional, Rio de Janeiro, pp. 175-196, dezembro.

MACCORMICK, N. e SUMMERS, R. (eds.). 1997. Interpreting Precedents - A comparative Study. Aldershot: Ashgate-Dartmouth.

MACCORMICK, N. e SUMMERS, R. (eds.). 1991. Interpreting Statutes. Farnham: Ashgate.

MENDES, R. L. T. 2010. Verdade real e livre convencimento: O processo decisório judicial brasileiro visto de uma perspectiva empírica. DILEMAS: Revista de Estudos de Conflito e Controle Social, Niterói, v.5, n.3, p.447-482, jul-set.

MERRY, S. E. 1995. Resistance and the Cultural Power of Law. Law \& Society Review, Amherst, v. 29, n. 1, pp. 11-26.

MERTZ, E. A. 1994. New Social Constructionism for Sociolegal Studies. Law and Society Review, Amherst, v. 28, n. 5, pp. 1243-1266.

MIAILLE, M. 2005. Introdução Crítica ao Direito. Lisboa: Estampa.

MOREIRA-LEITE, A. 2003. Em tempo de conciliação. Niterói: EdUFF.

O’DONNELL, G. 1972. Modernización y Autoritarismo. Buenos Aires: Paidos.

1979. Desenvolvimento Político ou Mudança Política? In: PINHEIRO, P. S. (Ed.). O Estado Autoritário e Movimentos Populares. Rio de Janeiro: Paz e Terra, pp. 23-95.

1991. Democracia delegativa? Novos Estudos CEBRAP, São Paulo, v. 31, pp. 25-40, outubro.

1994. Delegative Democracy. Journal of Democracy, Baltimore, v. 5, n. 1, pp. 55-69, janeiro.

pp. 5-31.

1996a. Uma Outra Institucionalização: América Latina e Alhures. Lua Nova, São Paulo, v. 37,

. 1996b. Poverty And Inequality In Latin America: Some Political Reflections. Working Paper $n^{\circ}$ 225, Kellogg Institute for International Studies - University of Notre Dame, Indiana.

. 1997. Polyarchies and the (Un)Rule of Law in Latin America: a Partial Conclusion. In: MENDEZ, J. et al (eds.). The (Un)Rule of Law \& the Underprivileged in Latin America. Indiana: Notre Dame U.P, pp. 303-337.

. 1998. Accountability Horizontal e Novas Poliarquias. Lua Nova, São Paulo, v. 44, p.27-54.

2000. Democracy, Law and Comparative Politics. IDS Working Paper $n^{\circ} 118$, Institute of Development Studies, Sussex, junho. 
2004. Quality of Democracy. Indiana: University of Notre Dame Press.

2010. Democracy, Agency, and the State: Theory with Comparative Intention. Oxford: Oxford UP.

2011. Democracia, Agência e Estado: Teoria com intenção comparativa. Rio de Janeiro: Paz e Terra.

, LAZZETTA, O. et al. (eds). 2011. Democracia delegativa. Buenos Aires: Prometeo.

,SCHMITTER, P. C. \& WHITEHEAD, L. (eds.). 1988. Transições do Regime Autoritário: América

Latina. Rio de Janeiro: Vértice, $4 \mathrm{v}$.

OLIVEIRA, M. R. et al. 2015. Judicialização da saúde: para onde caminham as produções científicas? Saúde em Debate [online]. 2015, v. 39, n. 105 , pp. 525-535. Disponível em: https://doi.org/10.1590/0103110420151050002019. Acesso em 20 Maio 2020

RAZ, J. 1979 [1977]. The Rule of Law and its Virtue. In: J. Raz (Ed.). The Authority of Law - essays on Law and Morality. Oxford: Clarendon, p.210-229

SADEK, M. T. 1998. Magistrados: uma imagem em movimento. Revista Brasileira de Ciências Sociais, São Paulo, v. 13, n. 38 .

SILBEY, S. 2005. After Legal Consciousness. Annual Review of Law and Social Science, v. 1, pp. 323-368. Disponível em: https://www.annualreviews.org/doi/abs/10.1146/annurev.lawsocsci.1.041604.115938, acesso em 25 maio 2020.

TAMANAHA, B. Z. 2004. On The Rule of Law: History, Politics, Theory. Cambridge: Cambridge UP.

TILLY, C. 1996. Coerção, Capital e Estados europeus 1990-1992. São Paulo: Edusp.

2013. Democracia. Petrópolis: Vozes.

TOKMAN, V.E.; O’DONNELL, G. (Eds.). 1998. Poverty and Inequality in Latin America. Indiana: Notre Dame UP.

VANNUCCHI, M. A. 2016a. Advogados e corporativismo de classe média no Brasil pós-1930. Passagens. Revista Internacional de História Política e Cultura Jurídica, Rio de Janeiro, v. 8, n. 3, pp. 506-525.

2016b. O corporativismo dualista: conselhos profissionais e sindicatos no Brasil, 1930-1964. Estudos Ibero-Americanos, Porto Alegre, v. 42, n. 2, pp. 471-99.

VIANNA, L. W. et al. 1997. Corpo e alma da magistratura brasileira. Rio de Janeiro: Revan.

WANG, D. W. L. et al. 2014. Os impactos da judicialização da saúde no município de São Paulo: gasto público e organização federativa. Revista de Administração Pública, São Paulo, v. 48, n. 5, p. 1191-1206.

WARAT, L. A. 1995. O Direito e sua linguagem - $2 a$ Versão. Porto Alegre: Sérgio Antônio Fabris.

WHITEHEAD, L. 2014. "A mí, si, me importa": Guillermo O'Donnell's approcach to theorizing with normative and comparative intent. In: BRINKS, D. et al (eds.). Reflections on Uneven Democracies: the legacy of Guillermo O'Donnell. Baltimore: John Hopkins UP, pp .333-351. 